\title{
Valuation Bias and Profit Opportunities in Financial Markets
}

\author{
Jayendra Gokhale ${ }^{1}$, Elizabeth Schroeder ${ }^{2} \&$ Victor J. Tremblay ${ }^{2}$ \\ ${ }^{1}$ Department of Economics, Finance and Information Systems, Embry Riddle Aeronautical University, USA \\ ${ }^{2}$ Departmernt of Economics, Oregon State Univeristy, USA \\ Correspondence: Elizabeth Schroeder, Department of Economics, 303 Ballard Extension Hall, Oregon State \\ University, Corvallis, Oregon, 97331-3612, USA. Tel: 1-541-737-1476. E-mail: liz.schroeder@oregonstate.edu
}

Received: January 10, 2014

Accepted: January 26, 2014

Online Published: March 25, 2014

doi:10.5539/ijef.v6n4p147

URL: http://dx.doi.org/10.5539/ijef.v6n4p147

\begin{abstract}
Recent work by Gokhale et al. (forthcoming) proposes a method for detecting misvalued stocks. This paper applies the method to look for profitable investment opportunities by identifying undervalued stocks. Using data on companies in the S\&P 100 over a period of 22 years, we test several specifications of our investment strategy for robustness. We find that investing in undervalued stocks significantly outperforms benchmark indices over time, and that this strategy can lead to risk-adjusted excess returns that are positive and statistically significant.
\end{abstract}

Keywords: investment opportunities, misvaluation, behavioral finance

\section{Introducation}

The field of behavioral finance analyzes how psychological forces may influence investor decisions and cause market anomalies (Note 1). The literature shows how the sentiment and cognitive weaknesses of some traders can cause them to over or under react to fundamental information and respond to news that is unrelated to economic fundamentals. Traders such as these are called noise traders (De Long et al., 1990), and their behavior can lead to valuation bias or misvaluation in which security prices deviate from their fundamental economic values. When such behavioral forces are coupled with herd behavior, this can produce booms, busts, and inefficient financial markets.

For advocates of the efficient markets hypothesis (EMH), swings in financial markets are merely responses to unanticipated events. Eventually, security prices must return to their fundamental values. One of the strongest criticisms of the behavioral finance literature is that methods which uncover misvaluation ex post have not led to profitable investment strategies ex ante. This position is clearly voiced by Roll (1992), (Note 2) a financial economist and a portfolio manager: "I have personally tried to invest money. in every single anomaly and predictive device that academics have dreamed up. And I have yet to make a nickel on any of these supposed market inefficiencies." After reviewing the evidence, Malkeil (2011) reaches the same conclusion, indicating that even if arbitrage opportunities did exist ex post, "it is extraordinarily difficult to recognize such situations ex ante."

The purpose of this paper is to show how a method developed by Gokhale et al. (forthcoming) can be used to identify valuation anomalies and uncover profitable investment opportunities. The methodology takes an estimation technique that is commonly used to identify inefficiency in production and cost models, and applies it to finance to look for misvalued stocks. In their paper, Gokhale et al. propose an investment strategy based on this test for misvaluation and evaluate it using the Dow, which includes 30 stocks, over a time period of six years surrounding the Great Recession. In light of the common difficulty in finding profit opportunities that hold up over time, we investigate this investment strategy further to determine whether it can be profitable using a broader stock index over a longer time period. In the next section, we briefly discuss this method. In Section III, we use it to determine whether or not a strategy of investing in undervalued stocks can earn excess returns. We use a simple investment rule that can be implemented by an average investor. Our results confirm that persistently buying undervalued stocks using this method can lead to positive risk-adjusted excess returns.

\section{The Composite-Error Model and Valuation Bias}

The composite-error model of financial returns, developed by Gokhale et al. (forthcoming), modifies the traditional market model to allow for over- or under-valuation by including a dual error term. In the standard 
market model, variation in a stock's return is explained by a combination of the variation in the overall market and an idiosyncratic error term specific to the individual stock. Here, a "market" portfolio containing all stocks is used to capture the available market information. In applications, the market portfolio is the Standard \& Poor 500 Index (S\&P 500). The return of stock i at time $\mathrm{t}\left(R_{i t}\right)$ is assumed to have a linear relationship that is stable over time with the return on the market portfolio, $\left(R_{m t}\right)$ (Note 3$)$ :

$$
R_{i t}=\alpha_{i}+\beta_{i} R_{m t}+\varepsilon_{i t}
$$

where the error term, $\varepsilon_{i t}$, is typically assumed to be normally distributed with zero mean.

The composite-error model is an extension of the market model and is distinguished by a dual error structure. In equation (1), market efficiency requires the error term to be white noise. Denoting the white noise associated with stock $\mathrm{i}$ at time $\mathrm{t}$ as $v_{i t}$, where $v_{i t} \sim N\left(0, \sigma_{v}^{2}\right)$, the market model sets $\varepsilon_{i t}=v_{i t}$ and assumes that there are no systematic biases in expected stock returns: $E\left[R_{i t} \mid R_{m t}\right]=\alpha_{i}+\beta_{i} R_{m t}$. The assumptions of the traditional market model hold if investors make mistakes that are uncorrelated.

In contrast, the composite-error model allows for systematic misvaluation by including a second error term, $\mu_{i t}$, such that $\varepsilon_{i t}=v_{i t}+\mu_{i t}$. This second error identifies valuation bias, which can arise when traders suffer from systematic behavioral biases. One example is when traders base investment decisions on market trends rather than economic fundamentals (Note 4). If such biases causes stock $\mathrm{i}$ at time $\mathrm{t}$ to be overvalued, then $\mu_{i t}>0$. In this case, the stock's returns outperform the returns that reflect economic fundamentals alone. If these biases cause undervaluation, on the other hand, then $\mu_{i t}<0$. An intuitively appealing assumption on the distribution of $\mu_{i t}$ is that smaller valuation errors are more common than large ones. One suitable assumption is that $\mu_{i t}$ is iid half-normal, which we use in this analysis. Other possible distributions are the truncated-normal, the exponential, and the gamma distributions. The traditional market model is a special case of the composite-error model in which there is no valuation bias: $\mu_{i t}=0$ and $v_{i t}=\varepsilon_{i t}$.

In the absence of any valuation bias, returns will reflect the fundamental value of a security. The composite-error model enables us to estimate the fundamental value of a stock in year $\mathrm{t}, R_{i t}^{*}$, and thus determine whether or not a stock is misvalued. Over- or under-valuation is reflected in the difference between the market value and the fundamental value of stock returns: $\mu_{i t}=R_{i t}-R_{i t}^{*}$. Thus the expected fundamental return is

$$
E\left(R_{i t}^{*}\right)=E\left(R_{i t}-\mu_{i t}\right)=\left(\alpha_{i}+\beta_{i} R_{m t}\right)
$$

If there is no valuation bias, then $\mu_{i t}=0$ and $R_{i t}^{*}=R_{i t}=\alpha_{i}+\beta_{i} R_{m t}+v_{i t}$. Except for the unanticipated white-noise error term, market and fundamental values coincide. In this case, the market is efficient and the market model accurately captures the relationship between $R_{i t}$ and $R_{m t}$.

If misvaluation is present, knowledge of the parameters of the composite-error model $\left(\alpha_{i}, \beta_{i}\right.$, and $\left.\mu_{i t}\right)$ can be used to estimate the fundamental value of returns. Equation (1) with a composite error term can be estimated using maximum likelihood. The maximum likelihood method provides estimates of $\sigma_{v}^{2}, \sigma_{\mu}^{2}$, and the coefficients of the model and their standard errors. These results allow us to estimate $\mu_{i t}$ (Greene, 2008). In this paper, our main concern is to identify undervalued stocks. With undervaluation, $\mu_{i t}$ is distributed as nonpositive half normal, $N\left(0, \sigma_{\mu}^{2}\right)$ (Note 5). Actual returns fall short of expected fundamental returns by $\left|\mu_{i t}\right|$ (Note 6). Notice that when $\sigma_{\mu} \rightarrow 0$, the distribution collapses to a spike at zero so that $\mu_{i t} \rightarrow 0$. There is no undervaluation in this case and the market model is the correct specification. Thus, the null hypothesis of interest is $\sigma_{\mu}=0$, which we test using a one-sided likelihood ratio test (Coelli, 1995). If the null hypothesis is rejected, then $\mu_{i t}$ is negative (i.e., $\varepsilon_{i t}$ is skewed in the negative direction), implying undervaluation.

\section{Investment Strategy}

The main purpose of the paper is to determine whether one can earn excess returns by continuously investing in undervalued stocks, as identified by the composite-error model. We devise an investment strategy that is forward looking and would be accessible to the average investor. The investor uses a holding period of one year, and the portfolio is rebalanced at the end of each year (Note 7). The sample includes all companies that were members of the S\&P 100 at the beginning of each year from 1990 through 2011.

The investing and rebalancing rules are as follows.

1) For each year from 1990 to 2010, the composite-error model is estimated for each stock in the S\&P 100, using the daily returns for that stock. This provides a determination of which stocks in the S\&P 100 were undervalued in each year. A stock is considered undervalued if the null hypothesis that $\sigma_{\mu}=0$ is rejected at either a $5 \%$ or $1 \%$ test size, depending on the specification (Note 8).

2) At the beginning of 1991, $\$ 100$ is distributed equally among stocks that were undervalued in 1990 (Note 9). 
3) At the beginning of 1992, the portfolio is rebalanced by investing all proceeds equally among stocks that were significantly undervalued in 1991.

4) This investment strategy is continued for each year through 2011.

For this strategy to be profitable, two conditions must hold. First, the model must correctly identify undervalued stocks. Second, the market must correct the misvaluation. Of course, with superior foresight and the ability to identify market turning points, a better strategy would be to (1) invest in stocks that are favored by noise traders and becoming overvalued and (2) short-sell overvalued stocks and buy undervalued stocks just before market corrections take place. Unfortunately, it is impossible to accurately predict market turning points. This highlights why our investment strategy is more realistic - it requires limited forecasting ability and capitalizes on the fact that prices will ultimately converge to their fundamental values.

To evaluate the success of this investment strategy, we perform several comparisons. First, we compare investing in the portfolio of undervalued stocks with the performance of investing in the S\&P 500, the Dow, and the 1-month Treasury Bill (T-Bill). The S\&P 500 and the Dow are standard stock market indices, and the return on T-Bills approximates the risk free rate of return. Our baseline specification assumes that all dividends are retained and not reinvested by the investor. Second, we perform the same comparison when stock dividends are reinvested in the appropriate portfolio of stocks (i.e., our undervalued stocks, S\&P 500 stocks, and Dow stocks). To assure that dividends are correctly measured for the market indices, we use indices for the exchange-traded funds (ETF): S\&P-500 ETF (SPY), which started in 1993, and Dow ETF (DIA), which started in 1999.

In the third method used to evaluate the performance of our investment strategy, we control for risk by estimating our portfolio's risk-adjusted excess return. To control for risk, we calculate the mean value of risk-adjusted excess returns $\left(X R_{t}\right)$ for our portfolio at the end of each year. For stock i, $X R_{i t}=\left(R_{i t}-R_{f t}\right)-$ $\hat{\beta}_{i}\left(R_{m t}-R_{f t}\right)$, where $R_{f t}$ is the risk free rate of return (the return on a 1-month Treasury Bill) and $\hat{\beta}_{i}\left(R_{m t}-\right.$ $R_{f t}$ ) is the risk premium. The $\hat{\beta}_{i}$ for stock $\mathrm{i}$ in year $\mathrm{t}$ is estimated by the capital asset pricing model (CAPM) using daily returns $R_{\mathrm{it}}$ for the same year (Note 10). In a fully efficient financial market, arbitrage will force $X R_{\mathrm{it}}$ to zero. If the average $X R_{\mathrm{it}}$ for all stocks in our portfolio is positive and significantly different from zero, then our investment strategy earns excess risk-adjusted positive returns over the sample period.

These methods require data on individual stocks of firms that were members of the S\&P 100 and data on the S\&P 500, SPY, the Dow, DIA, and the T-Bill. Relevant data are obtained from the Center for Research in Security Prices, Wharton Research Data Service at www.wrds-web.wharton.upenn.edu.

\section{Returns from Investing in Undervalued Stocks}

Table 1 summarizes the results from the composite-error model of undervaluation, listing the number of firms that were significantly undervalued at the 5 percent and 1 percent significance levels for each year. On average, there were slightly fewer than 19 firms undervalued at the 5\% significance level per year during the sample period, with a range from 8 to 37 firms in a given year. The number of firms undervalued at a 1 percent significance level ranged from 3 to 24 firms, averaging 12.6 firms per year. Interestingly, the number of undervalued stocks increased around the recessionary periods of 2001 and 2008. These are periods in which both noise traders and rational traders might be expected to shy away from the stock market, leading to undervaluation that would be corrected by the market over time.

The success of the baseline specification of our investment strategy can be seen in Table 2, which lists cumulative returns from choosing various investment strategies. An investment of $\$ 100$ in T-Bills in 1990 would be worth just over $\$ 210$ in 2011. This implies that the risk-free return over this time period was about 210 percent. A $\$ 100$ investment in the S\&P 500 or the Dow would be worth approximately $\$ 381$ and $\$ 415$, respectively, at the end of the sample period. Because the Dow includes only 30 stocks, making it more risky than the S\&P 500, it is not surprising that the average return is higher for the Dow.

The last two columns of Table 2 clearly indicate that investing in undervalued stocks earns greater returns than any of the benchmark portfolios. Investing $\$ 100$ in stocks that were undervalued at the 5-percent level of significance was worth approximately $\$ 676$ in 2011 , while investing in the portfolio of stocks undervalued at 1-percent significance resulted in $\$ 506$. This is an indication that our investment strategy is correctly identifying companies that are undervalued, and that the misvaluation is driven out over time. The gains from investing in the portfolio of stocks undervalued at 5-percent significance are an additional 83 percent of what would have been earned by investing in the Dow over the same time period. 
Table 1. The number of undervalued stocks and the average Fundamental Valuatino Index (FVI) for undervalued stocks

\begin{tabular}{lcc}
\hline & \multicolumn{2}{c}{ Number of Firms } \\
& 5\% Significance & 1\% Significance \\
\hline 1990 & 15 & 12 \\
1991 & 8 & 8 \\
1992 & 14 & 11 \\
1993 & 14 & 12 \\
1994 & 10 & 7 \\
1995 & 8 & 4 \\
1996 & 15 & 8 \\
1997 & 11 & 8 \\
1998 & 11 & 3 \\
1999 & 12 & 10 \\
2000 & 20 & 16 \\
2001 & 37 & 24 \\
2002 & 33 & 21 \\
2003 & 24 & 17 \\
2004 & 18 & 15 \\
2005 & 24 & 13 \\
2006 & 27 & 20 \\
2007 & 15 & 14 \\
2008 & 26 & 15 \\
2009 & 21 & 8 \\
2010 & 24 & 16 \\
2011 & 26 & 16 \\
Average & 18.77 & \\
\hline & & \\
& & \\
& 16 & 64 \\
\hline
\end{tabular}

Table 2. Cumulative Returns from Investing in T-Bills, the S\&P 500, the Dow, and in Undervalued Stocks, 1990-2011

\begin{tabular}{llllcc}
\hline \multicolumn{5}{c}{ Undervaluation Investment Strategy } \\
& T-Bills & S\&P 500 & Dow & 5\% Significance & 1\% Significance \\
\hline 1990 & 100 & 100 & 100 & 100 & 100 \\
1991 & 107.68 & 126.31 & 92.9 & 138.34 & 134.13 \\
1992 & 113.61 & 131.95 & 112.89 & 126.55 & 122.7 \\
1993 & 117.47 & 141.25 & 117.76 & 135.23 & 125.42 \\
1994 & 120.88 & 139.08 & 133.68 & 142.86 & 131.52 \\
1995 & 125.57 & 186.52 & 136.59 & 181.86 & 171.67 \\
1996 & 132.52 & 224.32 & 184.24 & 210.54 & 193.07 \\
1997 & 139.33 & 293.87 & 229.26 & 253.29 & 246.17 \\
1998 & 146.41 & 372.25 & 283.44 & 313.95 & 268.28 \\
1999 & 153.42 & 444.93 & 326.82 & 423.94 & 317.23 \\
2000 & 160.41 & 399.82 & 404.16 & 440.1 & 311.25 \\
2001 & 169.65 & 347.67 & 378.85 & 444.06 & 326.91 \\
2002 & 176.06 & 266.43 & 358.46 & 364.72 & 275.94 \\
2003 & 178.93 & 336.72 & 306.3 & 481.4 & 358.69 \\
2004 & 180.75 & 367 & 370.44 & 546.12 & 407.16 \\
2005 & 182.92 & 378.02 & 381.81 & 577.15 & 422.39 \\
2006 & 188.34 & 429.5 & 386.01 & 691.96 & 495.19 \\
2007 & 197.36 & 444.66 & 443.91 & 703.72 & 508.69 \\
2008 & 206.58 & 273.53 & 464.17 & 457.97 & 327.57 \\
2009 & 209.63 & 337.68 & 321.5 & 636.4 & 451.75 \\
2010 & 209.83 & 380.85 & 376.63 & 691.44 & 531.83 \\
2011 & 210.09 & 380.84 & 415.31 & 675.78 & 505.94 \\
\hline & & & & &
\end{tabular}


To investigate the robustness of these findings, we consider two variations on the undervaluation investment strategy. One concern with Table 2 is that it ignores dividends. If our investment strategy identifies stocks that pay proportionally lower dividends than the S\&P 500 and the Dow, then investing in stocks that are deemed undervalued by the composite-error model may be an inferior strategy. Our second specification addresses this issue by assuming that investors reinvest all dividends at the next rebalancing period. These returns are compared to those from investing in the ETF funds, SPY and DIA, with dividends reinvested in the same manner. Due to data availability, the time frame for this strategy is slightly shorter. Table 3 reports the results for investing in SPY and our investment strategy from 1993 to 2011, and Table 4 lists the results for SPY, DIA, and our investment strategy from 1999 to 2011. Both tables demonstrate that our investment strategy is relatively more profitable when dividends are reinvested. In Table 3, the 5-percent significance undervaluation portfolio now ends with $\$ 745$, compared to a $\$ 100$ investment in the SPY, which is worth $\$ 373$. Over the shorter time period in Table 4, the 5-percent portfolio ends at \$208, compared to the DIA, which is worth $\$ 139$. In general, since including dividends improves the relative performance of our investment strategy above the baseline specification, we can see that stocks that were identified as undervalued paid out above average dividends.

Table 3. Cumulative returns with dividends from investing in T-Bills, the SPDR S\&P 500 exchange traded fund (SPY), and in undervalued stocks, 1993-2011

\begin{tabular}{llccc}
\hline & \multicolumn{4}{c}{ Undervaluation Investment Strategy } \\
& T-Bills & SPY & 5\% Significance & 1\% Significance \\
\hline 1993 & 100 & 100 & 100 & 100 \\
1994 & 103.88 & 101.16 & 107.88 & 106.91 \\
1995 & 109.63 & 140.06 & 140.79 & 141.42 \\
1996 & 115.27 & 169.95 & 167.09 & 162.7 \\
1997 & 121.12 & 227.07 & 206.61 & 211.8 \\
1998 & 126.92 & 289.59 & 261.48 & 233.89 \\
1999 & 132.7 & 345.7 & 357.78 & 280.54 \\
2000 & 140.34 & 309.72 & 379.85 & 282.13 \\
2001 & 145.65 & 281.17 & 398.26 & 309.65 \\
2002 & 148.02 & 225.24 & 336.49 & 268.54 \\
2003 & 149.53 & 279.07 & 452.46 & 355.71 \\
2004 & 151.33 & 307.26 & 521.54 & 410.6 \\
2005 & 155.81 & 329 & 561.73 & 434.75 \\
2006 & 163.27 & 373.34 & 688.76 & 519.81 \\
2007 & 170.9 & 389.75 & 709.89 & 540.37 \\
2008 & 173.42 & 257.18 & 471.51 & 355.49 \\
2009 & 173.59 & 319.39 & 670.42 & 498.02 \\
2010 & 173.8 & 364.33 & 747.9 & 600.02 \\
2011 & 173.87 & 372.87 & 745.19 & 581.44 \\
\hline
\end{tabular}

The final step in our analysis is to determine whether or not the excess returns from our investment strategy simply result from greater risk. The risk premium associated with investing in our portfolio of stocks is based on beta estimates using the CAPM. If financial markets are efficient, risk-adjusted returns in excess of the risk free rate will be zero. Assuming that EMH holds, $X R$ is normally distributed with zero mean. Thus, the null hypothesis is that the mean of $X R_{i t}, \theta_{X R}$, equals 0 ; the alternative hypothesis is that our investment strategy earns nonzero excess returns: $\theta_{X R} \neq 0$.

Our results indicate that the investment strategy does generate excess returns that are significantly greater than zero. For the portfolio of stocks that are undervalued at a 5-percent significance level, the mean value of estimated excess returns over the sample period is 4.52 percent per year. This mean is significantly different from zero at all conventional test sizes, with a p-value of 0.004 . The portfolio of stocks that are undervalued at a 1-percent significance level have a mean of estimated excess returns of 3.52 percent. This average is significantly different from zero at a 5-percent test size, with a p-value of 0.04 . These results are based on beta estimates that derive from data from the current investment period (Note 11). 
Table 4. Cumulative returns with dividends from investing in T-Bills, the SPDR S\&P 500 ETF (SPY), the SPDR Dow Jones Industrial Average ETF (DIA), and in undervalued stocks, 1999-2011

\begin{tabular}{lllccc}
\hline & \multicolumn{5}{c}{ Undervaluation Investment Strategy } \\
& T-Bills & DIA & SPY & 5\% Significance & 1\% Significance \\
\hline 1999 & 100 & 100 & 100 & 100 & 100 \\
2000 & 105.76 & 95.13 & 89.6 & 106.2 & 100.6 \\
2001 & 109.75 & 91.54 & 81.34 & 111.35 & 110.41 \\
2002 & 111.55 & 79.78 & 65.16 & 94.08 & 95.75 \\
2003 & 112.68 & 98.37 & 80.74 & 126.5 & 126.84 \\
2004 & 114.03 & 103.18 & 88.89 & 145.81 & 146.41 \\
2005 & 117.41 & 106.27 & 95.18 & 157.05 & 155.02 \\
2006 & 123.03 & 124.54 & 108.01 & 192.56 & 185.35 \\
2007 & 128.78 & 133.4 & 112.76 & 198.47 & 192.68 \\
2008 & 130.68 & 95.05 & 74.4 & 131.83 & 126.76 \\
2009 & 130.81 & 114.21 & 92.4 & 187.44 & 177.58 \\
2010 & 130.97 & 128.74 & 105.4 & 209.1 & 213.95 \\
2011 & 131.02 & 139.94 & 107.87 & 208.34 & 207.32 \\
\hline
\end{tabular}

All of the evidence supports the conclusion that the composite-error model can identify anomalies in financial markets and can be used to identify undervalued stocks and earn excess risk-adjusted returns in the long run (Note 12).

\section{Conclusion}

According to the behavioral finance literature, the behavioral biases of investors can cause security prices to deviate from their fundamental values for a considerable length of time. In this study, we show how the composite-error model can identify undervalued stocks and be used to develop an investment strategy that earns excess risk-adjusted returns.

Our empirical evidence supports two conclusions. First, estimates from the composite-error model confirm that a considerable number of S\&P 100 stocks were undervalued during the 1990-2011 period. Second, we show how this information can be exploited to earn abnormal returns in the stock market. We develop a strategy that can be followed by an average investor, where annual investments are made in undervalued stocks. For the 1990-2011 period, this investment strategy substantially outperformed investing in the S\&P 500 and Dow indices. The evidence also shows that excess risk-adjusted returns from this investment strategy were significantly greater than zero during this time period.

In addition to revealing opportunities for profit, widespread use of the composite-error model can contribute to social welfare. Both rational and behaviorally biased traders will benefit from being able to better identify when a security is misvalued, knowledge that may cause prices to more closely approximate their fundamental values (Note 13). In addition, an ability to better estimate the degree of valuation bias in various markets can help the Federal Reserve meet its goal of fostering a more stable financial system.

\section{Acknowledgements}

We wish to thank Rolf Färe, Todd Pugatch, and Carol Tremblay for helpful comments on an earlier version of the paper. The investment strategy that is discussed in this paper is patent pending with the U.S. Patent Office, patent application number 61/696800.

\section{References}

Abreu, D., Markus, K., \& Brunnermeier, M. K. (2003). Bubbles and crashes. Econometrica, 71(1), 173-204. http://dx.doi.org/10.1111/1468-0262.00393

Aigner, D. J., Knox, L. C. A., \& Schmidt, P. (1977). Formulation and estimation of stochastic frontier production function models. Journal of Econometrics, 6, 21-37. http://dx.doi.org/10.1016/0304-4076(77)90052-5

Akerlof, G. A., \& Shiller, R. J. (2010). Animal spirits: How human psychology drives the economy, and why it matters for global capitalism. Princeton: Princeton University Press.

Allen, F., \& Gale, D. (2000). Financial contagion. Journal of Political Economy, 108(1), 1-33. http://dx.doi.org/10.1086/262109 
Allen, F., \& Gorton, G. (1993). Churning bubbles. Review of Economic Studies, 60, 813-836. http://dx.doi.org/10.2307/2298101

Allen, K., \& Sturcke, J. (2010, February 23). Timeline: Toyota's recall woes. The Guardian.

Avery, C., \& Zemsky, P. (1998). Multidimensional uncertainty and herd behavior in financial markets. American Economic Review, 88(4), 724-748.

Bailey, R. E. (2005). The economics of financial markets. Cambridge, UK: Cambridge University Press. http://dx.doi.org/10.1017/CBO9780511817458

Balvers, R., Wu, Y., \& Erik, G. E. (2000). Mean reversion across national stock markets and parametric contrarian investment strategies. Journal of Finance, 55(2), 745-772. http://dx.doi.org/10.1111/0022-1082.00225

Barber, B. M., Odean, T., \& Zhu, N. (2009). Systematic noise. Journal of Financial Markets, 12(4), 547-569. http://dx.doi.org/10.1016/j.finmar.2009.03.003

Barberis, N., \& Thaler, R. (2005). A survey of behavioral finance. In R. H. Thaler (Ed.), Advances in Behavioral Finance (pp. 1-78). Princeton, NJ: Princeton University Press.

Barberis, N., \& Thaler, R. (2003). A survey of behavioral finance. In G. M. Constantinides, M. Harris, \& R. M. Stulz (Eds.), Handbook of the Economics of Finance (pp. 1051-1121). Amsterdam: Elsevier.

Benartzi, S., \& Thaler, R. (1995). Myopic loss aversion and the equity premium puzzle. Quarterly Journal of Economics, 111(1), 75-92. http://dx.doi.org/10.2307/2118511

Bergstresser, D., \& Philippon, T. (2006). CEO incentives and earnings management. Journal of Financial Economics, 80, 511-529. http://dx.doi.org/10.1016/j.jfineco.2004.10.011

Bhagat, S., \& Romano, R. (2002a). Event studies and the law: Part I: Technique and corporate litigation. American Law and Economics Review, 4(1), 141-168. http://dx.doi.org/10.1093/aler/4.1.141

Bhagat, S., \& Romano, R. (2002b). Event studies and the law: Part II: Empirical studies of corporate law. American Law and Economics Review, 4(2), 380-423. http://dx.doi.org/10.1093/aler/4.2.380

Biais, B., Glosten, L., \& Spatt, C. (2005). Market microstructure: A survey of microfoundations, empirical results, and policy implications. Journal of Financial Markets, 8, 217-264. http://dx.doi.org/10.1016/j.finmar.2004.11.001

Black, F. (1986) Noise. Journal of Finance, 41(3), 529-543. http://dx.doi.org/10.1111/j.1540-6261.1986.tb04513.x

Blume, L., Easley, D., \& O'Hara, M. (1994). Market statistics and technical analysis: The role of volume. Journal of Finance, 49(1), 153-181. http://dx.doi.org/10.1111/j.1540-6261.1994.tb04424.x

Boudoukh, J., Feldman, R., Kogan, S., \& Richardson, M. (2012). Which news moves stock prices? A textual analysis. National Bureau of Economic Research, NBER Working Paper.

Brooks, R. M., Patel, A., \& Su, T. (2003). How equity market responds to unanticipated events. Journal of Business, 76(1), 109-133. http://dx.doi.org/10.1086/344115

Bunkley, N. (2010, January 21). Toyota issues a 2nd recall. The New York Times.

Coates, J. (2012). The hour between dog and wolf: Risk taking, gut feelings and the biology of boom and busts. New York, NY: Penguin Press.

Coelli, T. (1995). Estimators and hypothesis tests for a stochastic frontier function: A Monte Carlo analysis. Journal of Productivity Analysis, 6(3), 247-268. http://dx.doi.org/10.1007/BF01076978

De Bondt, W., Muradoglu, G., Shefrin, H., \& Staikouras, S. K. (2008). Behavioral finance: Quo vidis? Journal of Applied Finance, 19(Fall/Winter), 1-21.

De Long, J. B., Shleifer, A., Summers, L. H., \& Waldmann, R. J. (1990). Noise trader risk in financial markets. Journal of Political Economy, 98(4), 703-738. http://dx.doi.org/10.1086/261703

DeMarzo, P. M., Kaniel, R., \& Kremer, I. (2008). Relative wealth concerns and financial bubbles. Review of Financial Studies, 21(1), 19-50. http://dx.doi.org/10.1093/rfs/hhm032

Fama, E. F. (1965). The behavior of stock-market prices. The Journal of Business, 38(1), 34-105. http://dx.doi.org/10.1086/294743 
Fama, E. F. (1991). Efficient capital markets: II. The Journal of Finance, 46(5), 1575-1617. http://dx.doi.org/10.1111/j.1540-6261.1991.tb04636.x

Fama, E. F. (1998). Market efficiency, long-term returns, and behavioral finance. The Journal of Finance, 49(3), 283-306. http://dx.doi.org/10.1016/S0304-405X(98)00026-9

Färe, R., \& Grosskopf, S. (2003). New directions: Efficiency and productivity. Boston, MA: Kluwer Academic Publishers.

Farmer, J. D., \& Lo, A. W. (1999). Frontiers of finance: Evolution and efficient markets. Proceedings of the National Academy of Sciences, 96(18), 9991-9992. http://dx.doi.org/10.1073/pnas.96.18.9991

Fluck, Z., Malkiel, B. G., \& Quant, R. E. (1997). The predictability of stock returns: A cross-sectional simulation. Review of Economics and Statistics, 79(2), 176-183. http://dx.doi.org/10.1162/003465397556764

Friedman, M. (1953). The case for flexible exchange rates. In Essays in Positive Economics. Chicago, IL: Chicago University Press.

Gokhale, J., \& Tremblay, V. J. (2013). Toyota's accelerator pedal recall and stockholder wealth. Department of Economics, Oregon State University.

Gokhale, J., Tremblay, C. H., \& Tremblay, V. J. (forthcoming). Misvaluation and behavioral bias in financial markets. Journal of Behavioral Finance.

Greene, W. H. (2008). The economic approach to efficiency analysis. In H. O. Fried, C. A. K. Lovell, \& S. S. Schmidt (Eds.), The Measurement of Productive Efficiency and Productivity Growth (pp. 92-250). New York, NY: Oxford University Press. http://dx.doi.org/10.1093/acprof:oso/9780195183528.003.0002

Grossman, S. J., \& Stiglitz, J. E. (1980). On the impossibility of informationally efficient markets. American Economic Review, 70(3), 393-408.

Harrison, J. M., \& Kreps, D. M. (1978). Speculative investor behavior in a stock market with heterogeneous expectations. Quarterly Journal of Economics, 92(2), 323-336. http://dx.doi.org/10.2307/1884166

Jegadeesh, N., \& Titman, S. (1993). Returns to buying winners and selling losers: Implications for stock market efficiency. Journal of Finance, 48(1), 65-91. http://dx.doi.org/10.1111/j.1540-6261.1993.tb04702.x

Jensen, M. C. (1978). Some anomalous evidence regarding market efficiency. Journal of Financial Economics, 6(2/3), 95-101. http://dx.doi.org/10.2139/ssrn.244159

Keynes, J. M. (1936). The general theory of employment, interest and money. New York, NY: Harcourt, Brace and World Inc.

Krugman, P. (2009, September 2). How did economists get it so wrong? The New York Times.

Kumbhakar, S., \& Knox Lovell, C. A. (2000). Stochastic frontier analysi. New York, NY: Cambridge University Press. http://dx.doi.org/10.1017/CBO9781139174411

Kumbhakar, S., Baardsen, S., \& Lien, G. (2012). A new method for estimating market power with an application to norwegian sawmilling. Review of Industrial Organization, 40(2), 109-129. http://dx.doi.org/10.1007/s11151-012-9339-7

Kyle, A. S. (1985). Continuous auctions and insider trading. Econometrica, 53(6), 1315-1335. http://dx.doi.org/10.2307/1913210

Lakonishok, J., Shleifer, A., \& Vishny, R. W. (1994). Contrarian investment, extrapolation, and risk. Journal of Finance, 49(5), 1541-1578. http://dx.doi.org/10.1111/j.1540-6261.1994.tb04772.x

Lo, A. W. (2004). The adaptive markets hypothesis: Market efficiency from an evolutionary perspective. Journal of Portfolio Management, 30, 15-29. http://dx.doi.org/10.3905/jpm.2004.442611

Lo, A. W. (2007). Reconciling efficient markets with behavioral finance: The adaptive markets hypothesis. Journal of Investment Consulting, 7(2), 21-44.

MacKinlay, A. C. (1997, March). Event studies in economics and finance. Journal of Economic Literature, 35, 13-39.

Madhavan, A. (2000). Market microstructure: A survey. Journal of Financial Markets, 3, 205-258. http://dx.doi.org/10.1016/S1386-4181(00)00007-0

Malkiel, B. G. (2003). The efficient market hypothesis and its critics. The Journal of Economic Perspectives, 17(1), 59-82. http://dx.doi.org/10.1257/089533003321164958 
Malkiel, B. G. (2011). The efficient market hypothesis and the financial crisis. Working Paper, Princeton University.

Meeusen, W., \& Van Den Broeck, J. (1977). Efficiency estimation from cobb-douglas production functions with composed error. International Economic Review, 18(2), 435-444. http://dx.doi.org/10.2307/2525757

Poterba, J. M., \& Summers, L. H. (1988). Mean reversion in stock prices: Evidence and implications. Journal of Financial Economics, 22(1), 27-59. http://dx.doi.org/10.1016/0304-405X(88)90021-9

Roll, R. (1992). Volatility of U.S. and Japanese stock markets: A symposium. Journal of Applied Corporate Finance, 25-35.

Scheinkman, J., \& Xiong, W. (2003). Overconfidence and speculative bubbles. Journal of Political Economy, 111, 1183-1219. http://dx.doi.org/10.1086/378531

Schwert, G. W. (2003). Anomalies and market efficiency. In G. Constantinides, M. Harris, \& R. Stulz (Eds.), Handbook of the economics of finance (pp. 939-974). Amsterdam: North-Holland Publishing, 2003.

Shefrin, H. (2013). Asset pricing and behavioral economics. In H. K. Baker \& G. Filbeck (Eds.), Portfolio Theory and Management (pp. 73-95). New York, NY: Oxford University Press. http://dx.doi.org/10.1093/acprof:oso/9780199829699.003.0004

Shiller, R. J. (2003). From efficient markets theory to behavioral finance. Journal of Economic Perspectives, 17(1), 83-104. http://dx.doi.org/10.1257/089533003321164967

Shleifer, A., \& Summers, L. H. (1990). The noise trader approach to finance. Journal of Economic Perspectives, 4(2), 19-33. http://dx.doi.org/10.1257/jep.4.2.19

Stigitz, J. E. (1990). Symposium on bubbles. Journal of Economic Perspectives, 4(2), 13-18. http://dx.doi.org/10.1257/jep.4.2.13

Taylor, A. (2007, March 7). America's best car company. Fortune.

Thaler, R. H. (1999). The end of behavioral finance. Financial Analysts Journal, 55(6), $12-17$. http://dx.doi.org/10.2469/faj.v55.n6.2310

Vissing-Jorgensen, A. (2004). Perspectives on behavioral finance: Does 'Irrationality' disappear with wealth? Evidence from expectations and actions. In M. Gertler \& K. Rogoff (Eds.), NBER Macroeconomics Annual 2003 (Vol. 18, pp. 139-208). MIT Press.

Waldman, D. M. (1982). A stationary point for the stochastic frontier. Journal of Econometrics, 18(2), 275-279. http://dx.doi.org/10.1016/0304-4076(82)90041-0

\section{Notes}

Note 1. For reviews of this literature, see Fama (1998), Thaler (1999), Barberis and Thaler (2003, 2005), Shiller (2003), Vissing-Jorgensen (2004), De Bondt et al. (2008), Barber et al. (2009), Akerlof and Shiller (2010), and Shefrin (2013).

Note 2. Thaler $(1999,14)$ makes a similar argument.

Note 3. For a review of the market model and a discussion of its use in event studies, see MacKinlay (1997) and Bhagat and Romano (2002a, 2002b). Returns of stock $\mathrm{i}$ in period $\mathrm{t}$ (Rit) are defined as the percentage change in the stock price plus dividends per share (dit): $R_{i t}=\frac{p_{i t}-p_{i t-1}+d_{i t}}{p_{i t-1}}$.

Note 4. Although we argue that the primary source of bias is noise trading, misvaluation can also arise, for example, when top management deceives traders by manipulating the reported earnings of a company (Bergstresser and Philippon, 2006).

Note 5. If there is overvaluation, $\mu_{i t}$ would be distributed as nonnegative half normal, $\mathrm{N}^{+}\left(0, \sigma_{\mu}^{2}\right)$. For further discussion, see Gokhale et al. (forthcoming).

Note 6. That is, with undervaluation $E\left(R_{i t}^{*}\right)=R_{i t}-\mu_{i t}$ and $R_{i t}=E\left(R_{i t}^{*}\right)+\mu_{i t}$, where $\mu_{i t}<0$.

Note 7. According to Benartzi and Thaler (1995), it is natural for investors to re-evaluate their portfolios once a year, since they receive comprehensive mutual fund reports and pay income taxes once a year.

Note 8. Stocks that were traded for fewer than 15 trading days were excluded from the sample.

Note 9. Of course, rational traders could use a more sophisticated method, one that includes fundamental 
economic information about firm and market characteristics, something that we ignore. We implicitly assume that the initial investment is sufficiently large to avoid integer problems.

Note 10. For a discussion of this procedure, see Bailey (2005). We also consider beta estimates from the previous year, which we discuss shortly.

Note 11. If we estimate the risk premium based on data from the year prior to the investment period, the estimated annual mean excess returns equal 3.44 (2.48) percent for stocks that are undervalued at 5-percent (1-percent). Only the first estimate is significantly different from zero, with a p-value of $0.04(0.16)$ for stocks that are undervalued at 5-percent (1-percent). However, the estimated excess return from the 1-percent portfolio is significantly different from zero at a test size of $10 \%$ if we consider a one-sided alternative that our investment strategy generates positive excess returns: $\theta_{X R}>0$.

Note 12. This ignores that fact that transaction costs would diminish returns from our investment strategy. Nevertheless, our investment strategy remains profitable even if we assume generous transaction costs, as assumed by Fluck et al. (1997). Of course, transaction costs would be substantially lower today with the availability of internet trading.

Note 13. For example, Schwert (2003) found that when a new method uncovers profit opportunities, these opportunities quickly dissipate once the method become common knowledge.

\section{Copyrights}

Copyright for this article is retained by the author(s), with first publication rights granted to the journal.

This is an open-access article distributed under the terms and conditions of the Creative Commons Attribution license (http://creativecommons.org/licenses/by/3.0/). 